\title{
A laboratory investigation of consumer addition of UHT milk to lessen the erosive potential of fizzy drinks
}

IN BRIEF

- Illustrates the erosive capacity of a range of carbonated drinks.

- Describes a readily accessible form of consumer modification to such drinks.

- Indicates that the addition of $6.25 \mathrm{ml}$ of UHT milk to $25 \mathrm{ml}$ of drink significantly reduces the erosive potential of the majority of the carbonated drinks studied.

\author{
J. Syed ${ }^{1}$ and R. G. Chadwick ${ }^{2}$
}

VERIFIABLE CPD PAPER

\begin{abstract}
Introduction Much recent attention has been given to the erosive potential of carbonated beverages. Some have shown that the risks of developing erosion, if such drinks are consumed once daily and four times daily, are respectively 2.2 and 5.13 times greater than if they are not consumed at all. The addition of ultra-heat treated (UHT) milk to such beverages has been identified by a survey as common practice in Pakistan. It is known that the addition of calcium to orange juice and acidic candies reduces the capacity of these dietary items to produce dental erosion by the law of mass action. While potentially helpful, such a practice at manufacture may affect adversely product stability and flavour, thus compromising market share. As a result an alternative approach is for the consumer to carry out such modification. The addition of milk is one such potential means. Objective To assess the capacity of six brands of carbonated drinks to bring about dental erosion and determine if consumer modification by the addition of milk affected this. Design In vitrostudy. Method For each drink in both manufactured and consumer modified ( $25 \mathrm{ml}$ of drink with $6.25 \mathrm{ml}$ UHT milk) states, the $\mathrm{pH}$ and titratable acidity were measured. These assessments were also made for distilled water dilution of the manufactured drinks in the ratio of 1 part drink to 0.25 parts water. In addition, the effects of a 60 min exposure to the drinks in manufactured and consumer modified states, upon the surface microhardness and profile of human molar buccal tooth substance were determined. Results The addition of milk significantly increased the mean $\mathrm{pH}(\mathrm{p}<0.001)$ and decreased the mean titratable acidity $(p<0.001)$. Its addition had significantly more $(p<0.001)$ than a simple dilution effect upon these values. Milk addition significantly lessened $(p<0.001)$ the reductions in surface microhardness of tooth substance when exposed to the drinks except in the case of one beverage. There was, however, no significant effect ( $p$ $=0.0732$ ) of its inclusion upon the depth loss of tooth substance. Conclusions Within the limitations of this study, the addition of milk to carbonated beverages reduced overall their capacity to bring about dental erosion.
\end{abstract}

\section{INTRODUCTION}

Both the 1993 National Children's Dental Health Survey ${ }^{1}$ and the more recent 2003 Children's Dental Health Survey ${ }^{2}$ report a high prevalence of dental erosion in young people $(52-65 \%$ of children). Dental erosion is the physical result of a pathogenic, chronic and localised loss of dental hard tissue as a result of chemical etching away of tooth substance upon exposure to acid without bacterial

\footnotetext{
'Lecturer in the Department of Oral Biology, DOW University of Health Sciences, Pakistan/Formerly Postgraduate Research Student, The Dental School and Hospital, Dundee, UK $;{ }^{2 *}$ Clinical Senior Lecturer in Restorative Dentistry/Honorary Consultant in Restorative Dentistry, The Dental School and Hospital, Park Place, Dundee, DD1 4HN

*Correspondence to: Dr R. G. Chadwick

Email: r.g.chadwick@dundee.ac.uk
}

\section{Online article number E6}

Refereed Paper - accepted 28 August 2008

DOI: $10.1038 /$ sj.bdj.2009.8

${ }^{\circ}$ British Dental Journal 2009; 206: E6 involvement. ${ }^{3}$ This acid may derive from dietary intake, medication, regurgitation of stomach contents or prolonged exposure to an acidic external environment. ${ }^{3}$ In other words, the acid source may be either intrinsic (from within the body) or extrinsic (from outside the body). Whereas some have claimed to have found a clear causal relationship between exposure to dietary risk factors and the presence of erosion, ${ }^{4-6}$ others have not. ${ }^{7-10}$ Perhaps due to worldwide increases in the consumption of carbonated drinks by children, much attention has focussed upon their erosive potential. The risk of developing erosion, if such drinks are consumed once per day, has been calculated as 2.2 times that of one who does not consume such beverages. ${ }^{11}$ This rises to 5.13 times if such drinks are consumed more than four times daily. ${ }^{11}$ Worldwide consumption of such drinks in 2005 was around 77 litres per head of population. ${ }^{12}$

Given such large scale sales and the widespread popularity of such drinks, it is perhaps rather naïve to think that consumption would be lessened to any great extent by preventive health messages. An alternative strategy could be to promote consumer modification of such drinks to lessen their capacity to produce dental erosion. One potentially helpful modification is to raise the drink's calcium content by mixing it with cow's milk. The addition of ultra-heat treated (UHT) milk to carbonated beverages has been identified by a survey as common practice in Pakistan. ${ }^{13}$ A popular British Asian cookbook ${ }^{14}$ states that British Asians have been drinking cola mixed with milk since the 1970s. Indeed, others have demonstrated in vitro that the addition of calcium to orange juice results in 
a strong preventive effect upon dental erosion. ${ }^{15}$ In addition, the naturally high levels of calcium in fizzy mineral waters have been shown in the laboratory to inhibit hyroxyapatite dissolution. ${ }^{16}$ Furthermore, an in vitro study has demonstrated that the addition of calcium to acidic candies results in a reduction of their capacity to bring about dental erosion. ${ }^{17}$ Such additions, especially in the form of consumer self-modification with other edible products, are unlikely to raise regulatory obstacles.

Although it is thought that the addition of calcium will suppress demineralisation of dental enamel according to the principles of the law of mass action, it should not be ruled out that other mechanisms might also operate, including alterations to the properties of the tooth surface and any surface films, such as integuments, pellicle and dental plaque. ${ }^{18}$

The purpose of this in vitro study was to assess the capacity of six brands of carbonated drinks to bring about dental erosion and determine if the addition of milk affected this. It was not the primary aim of this work to make inter-drink brand comparisons.

\section{METHODS AND MATERIALS}

Table 1 gives details of the six drinks tested in this study as compiled from manufacturer's data. The capacity for each of these to produce dental erosion in vitro was determined in both the drinks' manufactured states and consumer modified states by determination of their $\mathrm{pH}$ and titratable acidity combined with measurements of both the surface microhardness and surface contour of prepared human tooth samples before and following immersion for 60 minutes in the drinks. Consumer drink modification was achieved by mixing four parts of manufactured drink with one part of UHT cow's milk (Tesco Stores Ltd., Cheshunt, EN8 9SL, UK).

\section{(i) Titratable acidity and initial drink $\mathrm{pH}$ determination}

For each drink, in both the manufactured and consumer modified states, five $25 \mathrm{ml}$ samples were titrated to a $\mathrm{pH}$ of 7.0 against $0.1 \mathrm{M}$ sodium hydroxide while being constantly stirred with a magnetic

\begin{tabular}{|c|c|}
\hline Brand & Manufacturer and composition (compiled from manufacturers' data) \\
\hline CocaCola & $\begin{array}{l}\text { CocaCola Enterprises Ltd., Uxbridge, UK } \\
\text { 1) Phosphoric acid, 2) carbonated water, 3) caramel E150 d, 4) caffeine, 5) sugar }\end{array}$ \\
\hline Pepsi Max & $\begin{array}{l}\text { Britvic Soft Drinks Ltd., Chelmsford, UK } \\
\text { 1) Phosphoric acid, 2) carbonated water, 3) caramel E150 d, 4) caffeine, } \\
\text { 5) sweeteners (aspartame, acesulfame) }\end{array}$ \\
\hline Diet Coke & $\begin{array}{l}\text { CocaCola Enterprises Ltd., Uxbridge, UK } \\
\text { 1) Phosphoric acid, 2) carbonated water, 3) caramel E150 d, 4) caffeine, } \\
\text { 5) sweeteners (aspartame, acesulfame) }\end{array}$ \\
\hline Sprite & $\begin{array}{l}\text { CocaCola Enterprises Ltd., Uxbridge, UK } \\
\text { 1) Citric acid, 2) carbonated water, 3) sugar, 4) preservative E211, } \\
\text { 5) acidity regulator E331 }\end{array}$ \\
\hline 7-Up & $\begin{array}{l}\text { Britvic Soft Drinks Ltd., Chelmsford, UK } \\
\text { 1) Citric acid, 2) carbonated water, 3) sugar, 4) acidity regulator } \\
\text { (sodium citrate), 5) malic acid }\end{array}$ \\
\hline Lucozade Orange & $\begin{array}{l}\text { GlaxoSmithKline Group of Companies, Brentford, UK } \\
\text { 1) Citric acid, 2) carbonated water, 3) sugar, 4) acidity regulator } \\
\text { (sodium citrate), 5) malic acid }\end{array}$ \\
\hline
\end{tabular}

stirrer. In addition, in order to exclude the possibility of a simple dilution effect of the consumer modification, five 25 $\mathrm{ml}$ samples of each drink, drawn from a mixture of $25 \mathrm{ml}$ drink plus $6.25 \mathrm{ml}$ distilled water, were titrated to a $\mathrm{pH}$ of 7.0 against $0.1 \mathrm{M}$ sodium hydroxide while being constantly stirred with a magnetic stirrer. In all experiments, both the initial $\mathrm{pH}$ and its change in response to the addition of increments of the alkali were measured using a calibrated temperature compensated $\mathrm{pH}$ electrode (Piccolo ATC, Hanna Instruments Inc., Highland Business Park, 584 Park East Drive, Woonsocket, 02895, USA).

The mean $\mathrm{pH}$ reading and volume of sodium hydroxide required to reach neutrality ( $\mathrm{pH}$ 7.0) were recorded. The mean and standard deviation of these values were calculated for each drink in both manufactured and consumer modified states. In addition, to facilitate future comparison with other studies, the mean volume of $0.1 \mathrm{M}$ sodium hydroxide required to neutralise one litre of drink was calculated. This was termed the standardised titratable acidity (STA).

\section{(ii) Effect upon the surface microhardness and contour of prepared human tooth samples}

In this part of the work the effect of a 60 minute exposure to each drink, in both manufactured form and consumer modified state, upon human buccal molar tooth substance was determined. For clarity the experimental stages may best be described under the subheadings (a) Tooth collection and preparation, (b) Immersion protocol, (c) Surface microhardness determination, and (d) Surface profile measurement.

\section{(a) Tooth collection, preparation and immersion}

The tooth tissue samples used in this study were produced from extracted molar teeth with unrestored non-carious buccal surfaces that had been collected in the UK for dental research prior to September 2006. All teeth used in this study were stored in a solution of 10\% hypochlorite prior to their use. The fluoride history of the teeth was unknown. Ethical approval was obtained from the Tayside Committee on Medical Research Ethics (REC reference number 06/S1402/104). This study used 60 teeth in total.

In order to prepare the tooth specimens, the buccal aspect of each tooth, following removal of the roots with an air rota under continuous water coolant irrigation, was temporarily glued to the base of a metset mounting mould (Buehler, Coventry, UK) using a cyanoacrylate cement (Loctite ${ }^{\circledR}$ Precision Superglue, Henkel Consumer Adhesives, Cheshire, UK). Thereafter the mould was assembled and the tooth embedded in epoxy resin (Bonda Clear Casting, Resin, Bondaglass Vost Ltd., Kent, UK) 

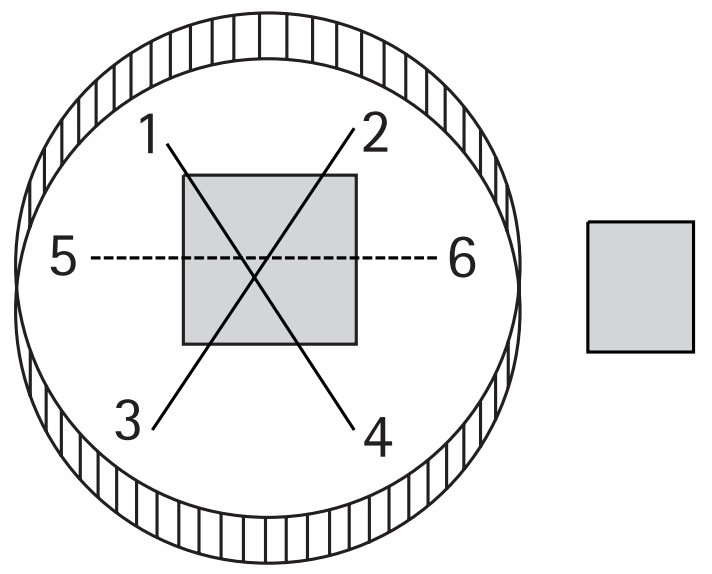

Surfaced Buccal enamel

Fig. 1 The reference indentations and lines. The indentations labelled 1, 2, 3 and 4 were used to mark the lines shown as -. The purpose of this was to identify four regions where hardness determination would be carried out. The indentations labelled 5 and $\mathbf{6}$ were used to established a line marked as -------, along which surface profiling was undertaken

mixed according to the manufacturers instructions. Once hardened the embedded tooth was removed from the mould and separated from the mould's base. The buccal enamel was then finished flush with the epoxy resin using a PM5 precision lapping and polishing machine (Longitech, Glasgow, Scotland) and slurry of calcined aluminium oxide powder with a particle size of 9 $\mu \mathrm{m}$ (Longitech, Glasgow, Scotland).

To enable subsequent identification, each specimen was numbered upon the mounting resin and allocated at random to a treatment group. Each treatment group consisted of five teeth and was designated as follows:

- Group A - exposure to $500 \mathrm{ml}$ CocaCola

- Group B -exposure to $500 \mathrm{ml}$ Pepsi Max

- Group C - exposure to $500 \mathrm{ml}$ Diet Coke

- Group D - exposure to $500 \mathrm{ml}$ Sprite

- Group E - exposure to $500 \mathrm{ml}$ 7-Up

- Group F - exposure to $500 \mathrm{ml}$ Lucozade Orange

- Group G - exposure to $400 \mathrm{ml}$ CocaCola mixed with $100 \mathrm{ml}$ milk

- Group H - exposure to $400 \mathrm{ml}$ Pepsi Max mixed with $100 \mathrm{ml}$ milk

- Group I - exposure to $400 \mathrm{ml}$ Diet Coke mixed with $100 \mathrm{ml}$ milk

- Group J - exposure to $400 \mathrm{ml}$ Sprite mixed with $100 \mathrm{ml}$ milk

- Group K - exposure to $400 \mathrm{ml}$ 7-Up mixed with $100 \mathrm{ml}$ milk
- Group L - exposure to $400 \mathrm{ml}$ Lucozade Orange mixed with $100 \mathrm{ml}$ milk.

Prior to making initial measurements, a number of reference indentations were placed on the mounting resin of each specimen using a number two round bur in a slow speed dental handpiece, surrounding the surfaced buccal enamel (Fig. 1). These comprised:

- Four indentations to facilitate surface hardness determination

- Two further indentations established a line, for surface profiling.

A fine-tipped marker pen was used to join these, as illustrated in Figure 1, to define four zones where hardness measurements would be undertaken (the apices of the four triangles formed by the lines $1-3,2-4)$ and the line along which surface profiling would be undertaken (line 5-6).

Prior to exposure of the tooth samples to the drinks in both manufactured and consumer modified form, the surface hardness and profile of each specimen was determined using the methods described below. It should be noted that any specimen found not to have a flat profile was rejected and replaced. Thereafter, to ensure that the datum for surface profiling was unaffected by subsequent exposure to the beverages, the entire surface enamel was masked with gaff tape (CPC, Preston, UK) other than a central circular region (of diameter 5 $\mathrm{mm}$ ) whose centre coincided with the intersection of lines 1-3 and 2-4 (Fig. 1).

\section{(b) Immersion protocol}

For each treatment group, following masking of the specimen surface, the specimens were placed in a $550 \mathrm{ml}$ sealable plastic container (Addis Clip and Close, Addis GP Ltd., Swansea, UK) with the tooth surface facing upwards. The container was placed upon the flat bed of a Stuart mini orbital shaker (Barloworld Scientific Ltd., Stone, Staffordshire, UK) and $500 \mathrm{ml}$ of the required test beverage was added. The container was sealed with its lid and the orbital shaker was set in motion at $70 \mathrm{rpm}$ for 60 minutes. Once this time had elapsed the specimens were removed and placed in distilled water to wash off the erosive medium. Thereafter the gaff tape was removed and the hardness and profile of each specimen re-determined. In all cases, due to the adhesiveness of the gaff tape removing the ink of the reference lines, the lines were re-marked prior to these measurements being undertaken.

\section{(c) Surface microhardness determination}

Surface microhardness determination for each specimen was carried out using a miniload hardness microscope (Ernest Leitz GmbH, D6330, Wetzlar, Germany) with a load of sufficient magnitude to produce a measurable indent (typically 200-300 g) applied for 20 seconds. Each specimen was subjected to four indentations before and following immersion. The testing sites were as near to the centre of the specimen as possible and within the four triangle apices indicated by the reference lines 1-3, 2-4 (Fig. 1). Surface microhardness for each indent was calculated using the formula:

Hardness value in $\mathrm{kg} \mathrm{mm}^{-2}=$

$(1854.4 \times \mathrm{P}) / \mathrm{d}^{2}$

Where $\mathrm{P}=$ applied weight in grams and $d=$ the length of the diamond indent in $\mu \mathrm{m}$.

The results for each drink combination were expressed as the mean Vickers hardness value and standard deviation of these observations. In addition, for each drink state (manufactured or consumer modified) the mean overall percentage reduction in surface hardness was calculated using the formula: 
$\%$ reduction in hardness $=(($ mean initial hardness - final mean hardness)/mean initial hardness) $\times 100$

\section{(d) Surface profile measurement}

This was determined for each specimen, following immersion for 60 minutes in the test beverage, using a profilometer (Surfometer Type SF 220, Planner Products Ltd, Sunbury on Thames, UK) with a stylus tip of diameter $20 \mu \mathrm{m}$. The speed of traverse throughout was $10 \mathrm{~mm} \mathrm{~min}^{-1}$. The instrument's software was used to calculate the mean depth loss relative to the protected surrounding enamel. Before its use, the instrument was calibrated using the manufacturer's calibration blocks which contained test grooves of 1,9 and $44 \mu \mathrm{m}$. In accordance with the manufacturer's instructions, no measurement work was undertaken within the first 20 minutes of turning the machine on. This was to allow evaporation of any moisture from the transducer head that would affect adversely its operation. For each treatment regime the results were expressed as the mean depth loss before and after immersion.

\section{RESULTS}

Tables 2 and 3 give the mean initial pH readings and mean titratable acidity, together with the standard deviations of these observations, for the drinks tested in both their manufactured and consumer modified states. In addition, the standardised titratable acidity values are presented. It should be emphasised that in the case of the modified drinks, $6.25 \mathrm{ml}$ of UHT British whole milk was added to $25 \mathrm{ml}$ of manufactured drink and it was in fact $25 \mathrm{ml}$ of the resultant mixture that was measured out for the determination of initial $\mathrm{pH}$ and titratable acidity. Table 3 also contains the standardised titratable acidity values.

Analyses of variance of the initial $\mathrm{pH}$ readings and of the titratable acidity of the drinks revealed, for both parameters, highly significant differences ( $p<0.0001$ ) between the drinks. These were localised by Tukey comparison of means testing. Tables 4 and 5 summarise the findings of these tests. It is clear that the addition of milk to any given drink highly significantly increased

Table 2 The mean pH readings of carbonated beverages in the raw state and following the addition of $6.25 \mathrm{ml}$ of Tesco's full fat UHT British whole milk

\begin{tabular}{l|l|l|l}
\hline Beverage & $\mathrm{pH}$ & Beverage & $\mathrm{pH}$ \\
\hline CocaCola & $3.56(0.03)$ & CocaCola + milk & $6.67(0.04)$ \\
\hline Pepsi Max & $3.86(0.03)$ & Pepsi Max + milk & $6.66(0.05)$ \\
\hline Diet Coke & $4.10(0.00)$ & Diet Coke + milk & $6.75(0.04)$ \\
\hline Sprite & $3.72(0.22)$ & Sprite + milk & $5.56(0.01)$ \\
\hline 7-Up & $3.38(0.13)$ & 7-Up + milk & $5.36(0.01)$ \\
\hline Lucozade Orange & $3.82(0.05)$ & Lucozade Orange + milk & $5.13(0.01)$ \\
\hline
\end{tabular}

Numbers in the body of the table represent the mean initial pH readings. Parenthesised values are the standard deviation. The mean is the
result of five experimental runs. In the case of those drinks where milk was added the mean is the result of five experimental runs of a 25
$\mathrm{ml}$ sample drawn from a dilution of $25 \mathrm{ml}$ drink plus $6.25 \mathrm{ml}$ milk.

\begin{tabular}{|c|c|c|c|c|c|}
\hline Beverage & $\begin{array}{l}\text { Titratable } \\
\text { acidity }\end{array}$ & $\begin{array}{l}\text { STA } \\
\mathrm{mol} / \mathrm{I} \times 10^{-2}\end{array}$ & Beverage & $\begin{array}{l}\text { Titratable } \\
\text { acidity }\end{array}$ & $\begin{array}{l}\text { STA } \\
\mathrm{mol} / \mathrm{I} \times 10^{-2}\end{array}$ \\
\hline CocaCola & $3.82(0.31)$ & 1.53 & $\begin{array}{l}\text { CocaCola } \\
+ \text { milk }\end{array}$ & $0.42(0.04)$ & 0.17 \\
\hline Pepsi Max & $3.82(0.48)$ & 1.53 & $\begin{array}{l}\text { Pepsi Max } \\
+ \text { milk }\end{array}$ & $1.78(0.51)$ & 0.71 \\
\hline Diet Coke & $3.28(0.18)$ & 1.31 & $\begin{array}{l}\text { Diet Coke } \\
+ \text { milk }\end{array}$ & $0.44(0.05)$ & 0.18 \\
\hline Sprite & $10.24(0.88)$ & 4.10 & Sprite + milk & $4.50(0.07)$ & 1.80 \\
\hline 7-Up & $11.08(0.29)$ & 4.43 & 7-Up + milk & $5.56(0.26)$ & 2.22 \\
\hline $\begin{array}{l}\text { Lucozade } \\
\text { Orange }\end{array}$ & $11.82(0.42)$ & 4.73 & $\begin{array}{l}\text { Lucozade } \\
\text { Orange + milk }\end{array}$ & $6.84(0.08)$ & 2.74 \\
\hline \multicolumn{6}{|c|}{$\begin{array}{l}\text { Numbers in the body of the table represent the mean volume ( } \mathrm{ml} \text { ) of } 0.1 \mathrm{M} \text { sodium hydroxide required to neutralise } 25 \mathrm{ml} \text { of drink. } \\
\text { Parenthesised values are the standard deviation. The mean is the result of five experimental runs. In the case of those drinks where milk } \\
\text { was added the mean is the result of five experimental runs of a } 25 \mathrm{ml} \text { sample drawn from a dilution of } 25 \mathrm{~m} / \mathrm{drink} \text { plus } 6.25 \mathrm{ml} \text { milk. }\end{array}$} \\
\hline \multicolumn{6}{|c|}{$\begin{array}{l}\text { The standardised titratable acidity (STA) is defined as the number of moles of } 0.1 \mathrm{M} \text { sodium hydroxide required to bring to } \mathrm{pH} 7.0 \text { one litre } \\
\text { of drink. It is calculated using the formula STA }=\text { (mean volume in } \mathrm{ml} \text { of } 0.1 \mathrm{M} \text { sodium hydroxide required to neutralise } 25 \mathrm{ml} \text { of drink } \\
\times 0.0001) \times 40 \text {. }\end{array}$} \\
\hline
\end{tabular}

( $\mathrm{p}<0.001$ ) the mean $\mathrm{pH}$ readings (Table 4). There was, however, no significant difference $(\mathrm{p}>0.05)$ in mean $\mathrm{pH}$ readings between CocaCola and 7-Up, Sprite and 7-Up, CocaCola with milk and Pepsi Max with milk, CocaCola with milk and Diet Coke with milk, and Pepsi Max with milk and Diet Coke with milk. For all other inter-drink comparisons the observed differences in mean $\mathrm{pH}$ readings were highly statistically significant ( $p<0.001$ ), except for CocaCola and Sprite, Pepsimax and Sprite, Pepsimax and Lucozade Orange, and 7-Up with milk and Lucozade Orange with milk, where the level of significance was $p$ $<0.01$. In the case of Sprite with milk compared to 7-Up with milk, the mean $\mathrm{pH}$ reading for 7-Up was significantly ( $p<0.05)$ lower.

Table 5 summarises the results of the Tukey comparison of means of the mean titratable acidity values observed for the drinks. The addition of milk to a given drink highly significantly ( $p<0.001$ ) decreased its mean titratable acidity. There was no significant difference ( $p$ $>0.05$ ) in mean titratable acidity values between: CocaCola and 7-Up, Sprite and 7-Up, CocaCola with milk and Pepsi Max with milk, CocaCola with milk and Diet Coke with milk, and Pepsi Max with milk and Diet Coke with milk. For all other inter-drink comparisons the observed differences in mean titratable acidity values were highly statistically significant ( $p<0.001)$ with the exceptions of Pepsi Max with milk and Diet Coke with milk, and Sprite with milk and 7-Up with milk, where the level of significance was $\mathrm{p}<0.01$.

Tables 6 and 7 give the mean initial $\mathrm{pH}$ readings and mean titratable acidity, together with the standard deviations of 


\begin{tabular}{|c|c|c|c|c|c|c|c|c|c|c|c|c|}
\hline versus & C & $P$ & D & $S$ & 7 & $\mathrm{~L}$ & $\mathrm{CM}$ & PM & $\mathrm{DM}$ & SM & $7 \mathrm{M}$ & LM \\
\hline C & - & $* * *$ & $* * *$ & * & NS & $* * *$ & $* * *$ & $* * *$ & $* * *$ & $* * *$ & $* * *$ & $* * *$ \\
\hline$P$ & - & - & $* *$ & * & $* * *$ & * & *** & $* * *$ & $* * *$ & $* * *$ & $* * *$ & $* * *$ \\
\hline D & - & - & - & *** & $* * *$ & $* * *$ & $* * *$ & $* * *$ & $* * *$ & $* * *$ & $* * *$ & $* * *$ \\
\hline$S$ & - & - & - & - & NS & $* * *$ & $* * *$ & $* * *$ & $* * *$ & $* * *$ & $* * *$ & $* * *$ \\
\hline 7 & - & - & - & - & - & $* * *$ & $* * *$ & $* * *$ & $* * *$ & $* * *$ & $* * *$ & $* * *$ \\
\hline L & - & - & - & - & - & - & $* * *$ & $* * *$ & $* * *$ & $* * *$ & $* * *$ & $* * *$ \\
\hline $\mathrm{CM}$ & - & - & - & - & - & - & - & NS & NS & $* * *$ & $* * *$ & $* * *$ \\
\hline PM & - & - & - & - & - & - & - & - & NS & $* * *$ & $* * *$ & $* * *$ \\
\hline DM & - & - & - & - & - & - & - & - & - & $* * *$ & $* * *$ & $* * *$ \\
\hline SM & - & - & - & - & - & - & - & - & - & - & * & $* * *$ \\
\hline $7 \mathrm{M}$ & - & - & - & - & - & - & - & - & - & - & - & $* *$ \\
\hline
\end{tabular}

Table 5 Results of Tukey comparison of means of mean titratable acidity values within Table 3

\begin{tabular}{|c|c|c|c|c|c|c|c|c|c|c|c|c|}
\hline versus & C & $P$ & D & $S$ & 7 & $\mathrm{~L}$ & $\mathrm{CM}$ & PM & $\mathrm{DM}$ & SM & $7 \mathrm{M}$ & LM \\
\hline C & - & NS & NS & $* * *$ & $* * *$ & *** & $* * *$ & $* * *$ & $* * *$ & NS & $* * *$ & $* * *$ \\
\hline$P$ & - & - & NS & $* * *$ & $* * *$ & *** & $* * *$ & $* * *$ & $* * *$ & NS & $* * *$ & $* * *$ \\
\hline D & - & - & - & $* * *$ & $* * *$ & $* * *$ & $* * *$ & $* * *$ & $* * *$ & $* * *$ & $* * *$ & $* * *$ \\
\hline$S$ & - & - & - & - & NS & $* * *$ & $* * *$ & $* * *$ & $* * *$ & $* * *$ & $* * *$ & $* * *$ \\
\hline 7 & - & - & - & - & - & NS & $* * *$ & $* * *$ & $* * *$ & $* * *$ & $* * *$ & $* * *$ \\
\hline L & - & - & - & - & - & - & $* * *$ & $* * *$ & $* * *$ & $* * *$ & $* * *$ & $* * *$ \\
\hline $\mathrm{CM}$ & - & - & - & - & - & - & - & $* * *$ & NS & $* * *$ & $* * *$ & $* * *$ \\
\hline PM & - & - & - & - & - & - & - & - & ** & $* * *$ & $* * *$ & *** \\
\hline DM & - & - & - & - & - & - & - & - & - & $* * *$ & $* * *$ & $* * *$ \\
\hline SM & - & - & - & - & - & - & - & - & - & - & ** & $* * *$ \\
\hline $7 \mathrm{M}$ & - & - & - & - & - & - & - & - & - & - & - & $* * *$ \\
\hline
\end{tabular}

$\mathrm{C}=$ CocaCola, $\mathrm{P}=$ Pepsi Max, D = Diet Coke, $\mathrm{S}=$ Sprite, $7=7-$-Up, $\mathrm{L}=$ Lucozade Orange, $\mathrm{CM}=$ CocaCola + milk, PM = Pepsi Max + milk, DM $=$ Diet Coke + milk, $S M=$ Sprite + milk, $7 M=7-U p+$ milk, $L M=$ L Lucozade Orange + milk.

NS $=$ No statistically significant difference; ${ }^{*}=p<0.05 ;^{* *}=p<0.01 ;{ }^{* * *}=p<0.001$.

these observations, for the drinks tested in consumer modified state $(6.25 \mathrm{ml}$ of UHT British whole milk was added to 25 $\mathrm{ml}$ of manufactured drink and $25 \mathrm{ml}$ of the resultant mixture measured out to determine initial $\mathrm{pH}$ and titratable acidity on five separate occasions) and water diluted state $(6.25 \mathrm{ml}$ of distilled water added to $25 \mathrm{ml}$ of manufactured drink and $25 \mathrm{ml}$ of the resultant mixture measured out to determine initial $\mathrm{pH}$ and titratable acidity on five occasions). In addition, the standardised titratable acidity values are also presented.
Analyses of variance of the initial $\mathrm{pH}$ readings and of the titratable acidity of the drinks in the consumer modified and water diluted states revealed, for both parameters, significant differences ( $p<0.0001$ ) between the drinks. Tukey comparison of mean testing demonstrated that, for a given drink brand, the consumer modified state consistently exhibited statistically significantly higher ( $\mathrm{p}<0.001$ ) initial mean $\mathrm{pH}$ readings and lower mean titratable acidity. As this aspect of the investigation was undertaken to see if the increases in initial $\mathrm{pH}$ and reductions in titratable acidity seen in Tables 2 and 3 were simply a dilution effect, no inter-drink comparisons are reported. From these results and their statistical comparison it is apparent that the addition of milk to the drink has more than a simple dilution effect upon both the mean $\mathrm{pH}$ reading and titratable acidity.

Table 8 gives the mean Vickers hardness values for the tooth samples before and following immersion in the drinks for 60 minutes. This table also gives the standard deviations of these observations and gives the mean change in surface microhardness. This latter quantity is also expressed as the percentage change in surface microhardness. For each drink the mean is calculated from five tooth samples measured at four sites. Thus each mean is a product of 20 indentations in total. For the drinks in manufactured and consumer modified states, separately conducted two way analyses of variance of the hardness measurements revealed highly significant ( $p<0.001$ ) effects of the type of drink and immersion upon this quantity. No significant interaction between these variables was found (manufactured state $\mathrm{p}=0.1892$, consumer modified state $\mathrm{p}$ $=0.6990$ ). Immersion in a given drink brought about a reduction in surface microhardness value. Due, however, to the variation in initial hardness values, the numerical change in hardness observed for each drink and state was converted to a percentage change in hardness to enable normalised comparison. This clearly revealed that overall the addition of milk reduced the decline in surface microhardness that followed drink immersion. This effect, as demonstrated by an analysis of variance of the percentage change in hardness, was statistically significant ( $p=0.005)$. The addition of milk thus significantly impaired the softening of the tooth samples, although this general observation must be tempered by the fact that this was not seen in the case of Sprite, where addition of milk brought about a slight increase in the percentage change in hardness (manufactured state $=47.3 \%$, consumer modified state $=58.9 \%$ ) .

Table 9 summarises the mean depth loss (with standard deviations) of tooth 
substance that occurred following a 60 minute exposure to each drink in the manufactured and consumer modified states while undergoing standardised agitation. An analysis of variance of this data returned a $\mathrm{p}$ value of 0.0732 and therefore the differences in depth loss values were not statistically significantly different.

\section{DISCUSSION}

This study employed a number of recognised laboratory tests to assess the potential of the drinks studied to bring about dental erosion in vitro.

The technique employed to assess the titratable acidity and to measure the initial $\mathrm{pH}$ was similar to that reported by others $^{19-22}$ but differed in that the volume of drinks tested was $25 \mathrm{ml}$ compared to $20 \mathrm{ml}$ as adopted by some of these workers. ${ }^{19-21}$ The results of the present study therefore are not directly comparable to these because they used a different volume of drink and evaluated other beverage types. Such a volumetric-based comparison may, however, be made if desired by multiplying the titratable acidity volumes reported in the literature (for evaluations involving a $20 \mathrm{ml}$ drink sample) by 1.25. In the future such inter-study comparison could be facilitated if all titratable acidity values were reported as the number of moles of $0.1 \mathrm{M}$ sodium hydroxide required to adjust the $\mathrm{pH}$ of a one litre of drink to $\mathrm{pH} 7.0$ (the standardised titratable acidity). Although reported here, such practice is not convention in the dental literature. A larger volume $(25 \mathrm{ml}$ ) of test beverage was used in the present work for it permitted greater depth of immersion of the $\mathrm{pH}$ electrode in the drink under test and facilitated the use of a magnetic stirrer, at constant rate, in the laboratory glassware used. Shellis et al. ${ }^{23}$ stated that reproducible stirring of erosive beverages in laboratory tests was essential for precision and intercomparison of in vitro erosion studies.

This study measured the surface microhardness of tooth specimens prior to and following immersion in the beverages in their manufactured and consumer modified states for 60 minutes. Inevitably, due to the nature of specimen preparation, the enamel tested was subsurface

Table 6 The mean pH readings of carbonated beverages in the water diluted and consumer modified states

\begin{tabular}{l|l|l|l} 
Beverage & $\mathrm{pH}$ & Beverage & $\mathrm{pH}$ \\
\hline CocaCola + water & $2.83(0.04)$ & CocaCola + milk & $6.67(0.04)$ \\
\hline Pepsi Max + water & $3.28(0.01)$ & Pepsi Max + milk & $6.66(0.05)$ \\
\hline Diet Coke + water & $3.56(0.01)$ & Diet Coke + milk & $6.75(0.04)$ \\
\hline Sprite + water & $3.54(0.01)$ & Sprite + milk & $5.56(0.01)$ \\
\hline 7-Up + water & $3.42(0.01)$ & 7-Up + milk & $5.36(0.01)$ \\
\hline Lucozade Orange + water & $3.31(0.01)$ & Lucozade Orange + milk & $5.13(0.01)$ \\
\hline
\end{tabular}

Numbers in the body of the table represent the mean initial pH readings. Parenthesised values are the standard deviation. The mean is the result of five experimental runs. In the case of those drinks where water was added, the mean is the result of five experimental runs of a 25
$\mathrm{ml}$ sample drawn from a dilution of $25 \mathrm{ml}$ drink plus $6.25 \mathrm{ml}$ water. In the case of those drinks where milk was added, the mean is the 2 . of five experimental runs of a $25 \mathrm{ml}$ sample drawn from a dilution of $25 \mathrm{ml}$ drink plus $6.25 \mathrm{ml}$ milk.

Table 7 The mean titratable acidity and standardised titratable acidity (STA) of carbonated beverages in the water diluted and consumer modified states

\begin{tabular}{|c|c|c|c|c|c|}
\hline Beverage & $\begin{array}{l}\text { Titratable } \\
\text { acidity }\end{array}$ & $\begin{array}{l}\text { STA } \\
\mathrm{mol} / \mathrm{I} \times 10^{-2}\end{array}$ & Beverage & $\begin{array}{l}\text { Titratable } \\
\text { acidity }\end{array}$ & $\begin{array}{l}\text { STA } \\
\mathrm{mol} / \mathrm{I} \times 10^{-2}\end{array}$ \\
\hline CocaCola + water & $4.08(0.08)$ & 1.63 & CocaCola + milk & $0.42(0.04)$ & 0.17 \\
\hline Pepsi Max + water & $4.24(0.09)$ & 1.70 & Pepsi Max + milk & $1.78(0.51)$ & 0.71 \\
\hline Diet Coke + water & $4.04(0.05)$ & 1.62 & Diet Coke + milk & $0.44(0.05)$ & 0.18 \\
\hline Sprite + water & $8.10(0.07)$ & 3.24 & Sprite + milk & $4.50(0.07)$ & 1.80 \\
\hline 7-Up + water & $8.70(0.14)$ & 3.48 & 7-Up + milk & $5.56(0.26)$ & 2.22 \\
\hline $\begin{array}{l}\text { Lucozade } \\
\text { Orange + water }\end{array}$ & $10.58(0.30)$ & 4.23 & $\begin{array}{l}\text { Lucozade Orange } \\
+ \text { milk }\end{array}$ & $6.84(0.08)$ & 2.74 \\
\hline \multicolumn{6}{|c|}{$\begin{array}{l}\text { Numbers in the body of the table represent the mean volume ( } \mathrm{mll} \text { ) of } 0.1 \mathrm{M} \text { sodium hydroxide required to neutralise } 25 \mathrm{ml} \text { of drink. Paren- } \\
\text { thesesised values are the standard deviation. The mean is the result of five experimental runs. In the case of those drinks where water was } \\
\text { added, the mean is the result of five experimental runs of a } 25 \mathrm{ml} \text { sample drawn from a dilution of } 25 \mathrm{ml} \text { drink plus } 6.25 \mathrm{ml} \text { water. In the } \\
\text { case of those drinks where milk was added, the mean is the result of five experimental runs of a } 25 \mathrm{ml} \text { sample drawn from a dilution of } 25 \\
\mathrm{ml} \text { drink plus } 6.25 \mathrm{ml} \text { milk. For an explanation of STA see Table } 3 \text {. }\end{array}$} \\
\hline
\end{tabular}

enamel. In the clinical situation, loss of surface enamel in function exposes subsurface enamel to direct acid contact so this is a relevant tissue to conduct this research upon. Hardness measurements permit an assessment of the degree of enamel and dentine dissolution to be made. $^{24}$ They have been shown to discriminate the erosive potentials of various substances applied to dental hard tissues, even after comparatively short exposures to acidic agents. ${ }^{25}$ It is somewhat misleading, however, to assume that the measurement is a reflection only of the surface properties. It should therefore be noted that the diamond indenter actually penetrates the surface of tooth substance by a few microns in such a test. With this point in mind it should be remembered that it is in fact the loss of mineral from the subsurface that initiates the erosive process by bringing about softening ${ }^{26}$ of the affected tooth substance. Some have commented that the length of indentations made in such tests, due to the flexibility of the dentine substrate, can change with time. ${ }^{27}$ These workers therefore advocate not measuring the dimensions of the indents until 24 hours after indentation. This raises a major practical problem, that of finding the indent again if other areas of the specimen are also indented at the same time. For this reason such a practice was not adopted in this study and this is in accord with others who have investigated erosion by microhardness determination. ${ }^{28-30}$

In the work reported here, a surface profilometer was used to determine the depth loss of tooth substance that occurred following exposure of the tooth samples to the beverages. Such an instrument has been used for this purpose by many other workers in laboratory erosion studies. ${ }^{15,31-34}$ Often tape is applied to the specimen prior to immersion to limit the area of tooth substance 
Table 8 The mean initial and final Vickers hardness values, and change in this (expressed as both numerical change and \% reduction), following immersion of the tooth samples in the beverages for 60 minutes

\begin{tabular}{|c|c|c|c|c|c|c|c|}
\hline Beverage & $\begin{array}{l}\text { Mean initial } \\
\text { hardness }\end{array}$ & $\begin{array}{l}\text { Mean final } \\
\text { hardness }\end{array}$ & $\begin{array}{l}\text { Numerical and } \\
\text { percentage change } \\
\text { in hardness }\end{array}$ & Beverage & $\begin{array}{l}\text { Mean initial } \\
\text { hardness }\end{array}$ & $\begin{array}{l}\text { Mean final } \\
\text { hardness }\end{array}$ & $\begin{array}{l}\text { Numerical and } \\
\text { percentage change } \\
\text { in hardness }\end{array}$ \\
\hline CocaCola & $175.7(109.0)$ & $68.7(41.8)$ & $\begin{array}{l}-107.0 \\
60.9 \%\end{array}$ & CocaCola + milk & 120.2 (91.6) & $111.3(92.3)$ & $\begin{array}{l}-8.9 \\
7.4 \%\end{array}$ \\
\hline Pepsi Max & 188.8 (122.0) & $74.7(48.9)$ & $\begin{array}{l}-114.1 \\
60.4 \%\end{array}$ & Pepsi Max + milk & $\begin{array}{l}166.0 \\
(160.6)\end{array}$ & 115.4 (83.5) & $\begin{array}{l}-50.6 \\
30.5 \%\end{array}$ \\
\hline Diet Coke & 195.5 (123.3) & $63.9(59.5)$ & $\begin{array}{l}-131.6 \\
67.3 \%\end{array}$ & Diet Coke + milk & $\begin{array}{l}251.4 \\
(132.3)\end{array}$ & $\begin{array}{l}186.8 \\
(136.0)\end{array}$ & $\begin{array}{l}-64.6 \\
25.7 \%\end{array}$ \\
\hline Sprite & $269.7(125.2)$ & $142.0(148.8)$ & $\begin{array}{l}-127.7 \\
47.3 \%\end{array}$ & Sprite + milk & $\begin{array}{l}249.2 \\
(139.9)\end{array}$ & $\begin{array}{l}102.3 \\
(69.8)\end{array}$ & $\begin{array}{l}-146.9 \\
58.9 \%\end{array}$ \\
\hline 7-Up & 239.2 (181.7) & $67.0(76.4)$ & $\begin{array}{l}-172.2 \\
72.0 \%\end{array}$ & 7-Up + milk & $\begin{array}{l}168.1 \\
(123.6)\end{array}$ & $112.2(80.5)$ & $\begin{array}{l}-55.9 \\
33.3 \%\end{array}$ \\
\hline Lucozade Orange & $160.2(115.9)$ & $57.9(20.1)$ & $\begin{array}{l}-102.3 \\
63.9 \%\end{array}$ & $\begin{array}{l}\text { Lucozade Orange } \\
+ \text { milk }\end{array}$ & $297.5(268.2)$ & $\begin{array}{l}166.7 \\
(121.9)\end{array}$ & $\begin{array}{l}-130.8 \\
44.0 \%\end{array}$ \\
\hline
\end{tabular}

Mean overall percentage reduction in surface hardness in manufactured state $=62.0 \%(8.4)$

Mean overall percentage reduction in surface hardness in modified state $=33.3 \%(17.4)$

For each drink the mean is calculated from the surface hardness measurements of five tooth samples at four sites in each. The standard deviations of the observations

are given in parentheses.

The percentage reduction in hardness is calculated using the formula ((mean initial hardness - final mean hardness)/mean initial hardness) × 100 .

Table 9 The mean depth loss of tooth substance following immersion with standardised agitation for one hour in carbonated beverages in the raw state and following modification with Tesco's full fat UHT British whole milk

\begin{tabular}{|l|l|l|l|} 
Beverage & $\begin{array}{l}\text { Mean depth loss } \\
(\mu \mathrm{m})\end{array}$ & Beverage & $\begin{array}{l}\text { Mean depth loss } \\
(\mu \mathrm{m})\end{array}$ \\
\hline CocaCola & $4.47(2.74)$ & CocaCola + milk & $2.39(2.56)$ \\
\hline Pepsi Max & $2.30(2.13)$ & Pepsi Max + milk & $4.68(3.47)$ \\
\hline Diet Coke & $4.17(2.61)$ & Diet Coke + milk & $8.92(7.74)$ \\
\hline Sprite & $2.37(1.75)$ & Sprite + milk & $2.90(1.33)$ \\
\hline 7-Up & $\begin{array}{l}6.37(3.37) \\
n=4\end{array}$ & 7-Up + milk & $7.23(4.54)$ \\
\hline Lucozade Orange & $7.47(5.48)$ & Lucozade Orange + milk & $2.81(1.77)$ \\
\hline
\end{tabular}

Parenthesised values within the table are the standard deviation of the observations. Each mean is the product of profiles of three separate Parenthesised values within the table
specimens except where $n$ is quoted.

An analysis of variance of this data returned a p value of 0.0732 .

that is exposed to the eroding medium. This was the case in this work but unlike the procedures adopted by others, where the exposed region is a narrow strip 2-3 $\mathrm{mm}$ wide, the method of masking in this work left a circular region of diameter 5 $\mathrm{mm}$ and area of $19.63 \mathrm{~mm}^{2}$ exposed to the eroding media. Such a comparatively large area was thought to represent more realistically the in vivo situation, for the larger area was more exposed to the flow of the erosive medium brought about by the agitation of the tooth specimens than a narrow strip. The depth of erosion has previously been shown to increase proportionally with the velocity of the eroding liquid. ${ }^{23}$ In addition, the larger area more readily permitted surface microhardness determination. Perhaps due to a surface sheltering effect of the masking at the periphery of the exposed area, the loss of tooth substance seen in this work followed a bowl crater-like pattern. For this reason the mean depth loss along the line of profile was calculated, using the profilometer's software, to enable comparisons to be made.

The results of the work reported here clearly show that the addition of milk to the beverages, under the conditions of the study, significantly increased their mean initial $\mathrm{pH}$ readings (Table $2, \mathrm{p}<0.001$ ), decreased their mean titratable acidity (Table 3, p <0.001) and significantly lessened (in all but one case) the percentage deterioration in surface microhardness that followed immersion of the tooth specimens in the beverages (Table $8, \mathrm{p}=$ $0.005)$. Presumably this is due to a mineral exchange mechanism, for the calcium content of these products is high. Although the addition of milk to the drinks by the consumer shows considerable potential to lessen their capacity to produce dental erosion, it would be necessary to conduct a carefully controlled clinical study. In addition, work on the acceptability of this practice to the palate would also need to be undertaken. Acid content of foods/ beverages is an important factor in taste perception $^{35}$ and in addition, is a potent salivary stimulant. ${ }^{36}$ It would therefore be important to conduct further research to ensure that the potential in vivo beneficial effects of milk addition to carbonated beverages is not offset by potential reductions in saliva production.

Notwithstanding the above, the addition of milk to the beverages had no significant effect upon the mean depth loss due to erosion observed by profilometry, as compared to that of the beverages in manufactured state (Table 9). It could be that with greater specimen agitation, greater tooth tissue loss would have occurred of statistical significance, for the depth of erosion is known to increase proportionally with liquid velocity. ${ }^{23}$ Although the present work was conducted in vitro, it should also be borne in mind that in vivo 
softened tooth substance would also be subjected to the processes of abrasion and attrition. These were absent in the work presented here and are well known to increase tooth tissue loss. ${ }^{37}$

Of course, one may criticise the present work on the grounds that the lengthy immersion time of 60 minutes was longer than that encountered in vivo. It should be noted, however, that within the literature there is wide variation in immersion times. These range from 5 minutes $^{38}$ to 8 days, ${ }^{28}$ with the norm being of the order of 15-60 minutes. ${ }^{39}$ What is accepted, however, is that there is a critical exposure time that must be exceeded before a reduction in surface microhardness due to erosion occurs. ${ }^{28}$ It should also be mentioned that the experimental model in the present work did not mimic the remineralisation effects of saliva upon tooth substance.

Finally, it is interesting to note that in focus group discussions involving 32 children aged 8-14 years, concerning the prevention of the dental effects of carbonated drinks, the younger children recommended increasing the availability of milk and water. ${ }^{40}$ To promote this they developed the slogan 'Milk would make you the strongest person in the world'. Perhaps this apparent enthusiasm may, in the future, make the practice of adding milk to carbonated beverages acceptable for the prevention of dental erosion.

\section{CONCLUSION}

Within the limitations of this study, the addition of milk to carbonated beverages overall reduced their capacity to bring about erosion by significantly increasing their mean $\mathrm{pH}(\mathrm{p}<0.001)$ and decreasing both their mean titratable acidity ( $p<0.001)$ and the percentage change in surface microhardness of tooth substance following exposure to the beverages $(p=0.005)$.
The authors express their thanks to Val Wilson for preparation of the tooth specimens for testing.

1. O'Brian M. Children's dental health in the United Kingdom 1993. London: Office of Population Census and Surveys - Social Survey Division, HMSO, 1994.

2. Chadwick B, Pendry L. Non-carious dental conditions - children's dental health in the United Kingdom, 2003. London: Office for National Statistics, 2004.

3. Ten Cate J M, Imfeld T. Dental erosion, summary. Eur J Oral Sci 1996; 104: 241-244.

4. Lussi A, Schaffner M, Hotz P, Suter P. Dental erosion in a population of Swiss adults. Community Dent Oral Epidemiol 1991; 19: 286-290.

5. Al-Dlaigan Y H, Shaw L, Smith A. Dental erosion in a group of British 14-year-old school children. Part II: influence of dietary intake. Br Dent J 2001; 190: 258-261.

6. Al-Majeed I, Maguire A, Murray J J. Risk factors for dental erosion in 5-6 year old and 12-14 year old boys in Saudi Arabia. Community Dent Oral Epidemiol 2002; 30: 38-46.

7. Bartlett D W, Coward PY, Nikkah C, Wilson R F. The prevalence of tooth wear in a cluster sample of adolescent school children and its relationship with potential explanatory factors. Br Dent J 1998; 184: 125-129.

8. Williams D, Croucher R, Marcenes W, O'Farrell M. Prevalence of dental erosion in the maxillary incisors of 14-year-old schoolchildren living in Tower Hamlets and Hackney, London, UK. Int Dent J 1999; 49: 211-216.

9. Walker A, Gregory J, Bradnock G, Nunn J H, White D. National diet and nutrition survey. Young people aged 4-18 years, volume 2: report of the oral health survey. London: The Stationery Office, 2000.

10. Chadwick R G, Mitchell H L, Manton S L, Ward S, Ogston S, Brown R. Maxillary incisor palatal erosion: no correlation with dietary variables? J Clin Pediatr Dent 2004; 29: 157-163.

11. Dugmore C R, Rock W P. A multifactorial analysis of factors associated with dental erosion. Br Dent J 2004; 196: 283-286.

12. Anon. World consumption of soft drinks on rise. Food and Drink Weekly 2006 April 17. Available at http://findarticles.com/p/articles/mi_mOEUY/ is_16_12/ai_n16133094/pg_1?tag=artBody; col1 (accessed 23 December 2008).

13. Syed J. Determination and modification of drink erosive factors. Dundee: University of Dundee, 2007. MDSc Thesis.

14. Bhogal V. Cooking like mummyji. London: Simon \& Schuster UK Ltd, 2003. ISBN 0-74323-982-2.

15. Larsen M J. Nyvad B. Enamel erosion by some soft drinks and orange juices relative to their $\mathrm{pH}$, buffering effect and contents of calcium phosphate. Caries Res 1999; 33: 81-87.

16. Parry J, Shaw L, Arnaud M J, Smith A J. Investigation of mineral waters and soft drinks in relation to dental erosion. J Oral Rehabil 2001; 28: 766-772.

17. Jensdottir T, Nauntofte B, Buchwald C, Bardow A Effect of calcium on the erosive potential of acidic candies in saliva. Caries Res 2007; 41: 68-73.

18. Grenby TH. Lessening dental erosive potential by product modification. Eur J Oral Sci 1996; 104: 221-228.

19. Rees J S, Hughes J, Innes C. An in vitro assessment of the erosive potential of some white wines. Eur Prosthodont Restor Dent 2002; 10: 37-42.

20. Rees J S, Griffiths J. An in vitro assessment of the erosive potential of conventional and white ciders. Eur J Prosthodont Restor Dent 2002; 10: 167-171.

21. Phelan J, Rees J S. The erosive potential of some herbal teas. J Dent 2003; 31: 241-246.

22. Brown C J, Smith G, Shaw L, Parry J, Smith A J. The erosive potential of flavoured sparkling water drinks. Int J Paediatr Dent 2007; 17: 86-91.

23. Shellis R P, Finke $M$, Eisenburger $M$, Parker D M, Addy M. Relationship between enamel erosion and liquid flow rate. Eur J Oral Sci 2005; 113: 232-238.

24. Attin T. Methods for assessment of dental erosion. Monogr Oral Sci 2006; 20: 152-172.

25. Lussi A, Kohler N, Zero D, Schaffner M, Megert B. A comparison of the erosive potential of different beverages in primary and permanent teeth using an in vitro model. Eur J Oral Sci 2000; 108: 110-114.

26. Koulourides T. Experimental changes of mineral density. In Harris R S (ed) Art and science of dental caries research. pp 355-378. New York: Academic Press, 1968.

27. Herkstroter F M, Witjes M, Ruben J, Arends J. Time dependency of microhardness indentations in human and bovine dentine compared with human enamel. Caries Res 1989; 23: 342-344.

28. Maupome G, Diez-de-Bonilla J, Torres-Villasenor G. Andrade-Delgado L C. Castano V M. In vitro quantitative assessment of enamel microhardness after exposure to eroding immersion in a cola drink. Caries Res 1998; 32: 148-153.

29. Seow W K, Thong K M. Erosive effects of common beverages on extracted premolar teeth. Aust Dent J 2005; 50: 173-178.

30. Mahoney E. Preliminary in vitro assessment of erosive potential using the ultra micro indentation system. Caries Res 2003; 37: 218-224

31. Hughes J A, West N X, Parker D M, Van den Brack $\mathrm{M} \mathrm{H}$, Addy M. Effects of $\mathrm{pH}$ and concentrations of citric, malic and lactic acids on enamel, in vitro. J Dent 2000: 28: 147-152.

32. West N X, Hughes J A, Addy M. Erosion of dentine and enamel in vitro by dietary acids: the effect of temperature, acid character, concentration and exposure time. J Oral Rehabil 2000; 27: 875-880.

33. West N X, Hughes J A, Addy M. The effect of pH on the erosion of dentine and enamel by dietary acids in vitro. J Oral Rehabil 2001; 28: 860-864.

34. Rees J, Loyn T, McAndrew R. The acidic and erosive potential of five sports drinks. Eur J Prosthodont Restor Dent 2005; 13: 186-190.

35. Chadwick R G. The effect of cooking method upon the titratable acidity of a popular vegetarian dish - scope for reducing its erosive potential? Eur J Prosthodont Restor Dent 2006; 14: 28-31.

36. Jenkins $G$ N. The physiology and biochemistry of the mouth. 4th ed. Oxford: Blackwell Scientific, 1978

37. Addy M, Shellis R P. Interaction between attrition, abrasion and erosion in tooth wear. Monogr Oral Sci 2006; 20: 17-31.

38. Lippert F, Parker D M, Jandt K D. Susceptibility of deciduous and permanent enamel to dietary acid-induced erosion studied with atomic force microscopy nanoindentation. Eur J Oral Sci 2004; 112: 61-66.

39. Rees J. The role of drinks in erosion. Oral Health Report 2007: 1: 11-16.

40. May J, Waterhouse P J. Dental erosion and soft drinks: a qualitative assessment of knowledge, attitude and behaviour using focus groups of school children. A preliminary study. Int J Paediatr Dent 2003; 13: 425-433. 